\title{
Soil microbiological properties and enzymatic activities of long-term post-fire recovery in dry and semiarid Aleppo pine (Pinus halepensis M.) forest stands
}

\author{
J. Hedo ${ }^{1}$, M. E. Lucas-Borja ${ }^{2}$, C. Wic ${ }^{2}$, M. Andrés-Abellán ${ }^{2}$, and J. de Las Heras ${ }^{1}$ \\ ${ }^{1}$ Department of Plant Production and Agricultural Technology, School of Advanced Agricultural Engineering, \\ Castilla La Mancha University, Campus Universitario s/n, CP 02071, Albacete, Spain \\ ${ }^{2}$ Department of Agroforestry Technology and Science and Genetics, School of Advanced Agricultural Engineering, \\ Castilla La Mancha University, Campus Universitario s/n, CP 02071, Albacete, Spain
}

Correspondence to: J. Hedo (javier.hedo@gmail.com)

Received: 11 September 2014 - Published in Solid Earth Discuss.: 22 October 2014

Revised: 8 January 2015 - Accepted: 8 January 2015 - Published: 20 February 2015

\begin{abstract}
Wildfires affecting forest ecosystems and post-fire silvicultural treatments may cause considerable changes in soil properties. The capacity of different microbial groups to recolonise soil after disturbances is crucial for proper soil functioning. The aim of this work was to investigate some microbial soil properties and enzyme activities in semiarid and dry Aleppo pine (Pinus halepensis M.) forest stands. Different plots affected by a wildfire event 17 years ago without or with post-fire silvicultural treatments 5 years after the fire event were selected. A mature Aleppo pine stand, unaffected by wildfire and not thinned was used as a control. Physicochemical soil properties (soil texture, $\mathrm{pH}$, carbonates, organic matter, electrical conductivity, total $\mathrm{N}$ and $\mathrm{P}$ ), soil enzymes (urease, phosphatase, $\beta$-glucosidase and dehydrogenase activities), soil respiration and soil microbial biomass carbon were analysed in the selected forests areas and plots. The main finding was that long time after this fire event produces no differences in the microbiological soil properties and enzyme activities of soil after comparing burned and thinned, burned and not thinned, and mature plots. Moreover, significant site variation was generally seen in soil enzyme activities and microbiological parameters. We conclude that total vegetation recovery normalises post-fire soil microbial parameters, and that wildfire and post-fire silvicultural treatments are not significant factors affecting soil properties after 17 years.
\end{abstract}

\section{Introduction}

Fire is one of the most important disturbances in the Mediterranean region, as it shapes and structures many plant communities, forest ecosystems and landscapes (Boydak et al., 2006). After a fire event, forest functions, nutrient cycling, and the physical, chemical and biological properties of soils are significantly affected (Wic-Baena et al., 2013), and runoff and surface erosion rates can greatly increase (Prats et al., 2013). Moreover, global change is affecting fire regime, increasing fire frequency, area burned, and its destructiveness to Mediterranean ecosystems (Pausas, 2004). In this context, post-fire forest management is useful to accelerate the recovery of soil forest functions, and to improve health, growth and reproductive processes (Moya et al., 2008). For fire-adapted pines, such as Pinus pinaster Ait. (Maritime pine) and Pinus halepensis Mill. (Aleppo pine), three main forest management guidelines have been proposed as proper post-fire silvicultural treatments. The guidelines are in accordance with the success of natural regeneration: (1) no treatments if natural regeneration is achieved after the fire event; (2) assisted natural regeneration or (3) active restoration (De las Heras et al., 2012). Moreover, several studies have shown that early thinning reduces both intra-specific competition and fire recurrence events (Espelta et al., 2008).

Soil plays an essential role in the forest ecosystem's fertility and stability (Smith and Papendick, 1993). Also, soil microorganisms accomplish reactions to release soil nutrients for vegetation development (Hannam et al., 2006). As 
Rutigliano et al. (2004) reported, microbial biomass and activity increased from younger to later stages of ecological succession and the introduction of pine into Mediterranean areas retards soil development. However, soil properties and plant cover relationships can be in various ways at various rates, and since different studies were not replicated across a range of site types, conclusions cannot be generalized (Muscolo et al., 2007). Forest fires and post-fire silvicultural treatments may significantly change forest and soil properties (Grady and Hart, 2006; Wic-Baena et al., 2013). After forest fires, changes in vegetation dynamics and soil properties are expected to occur due to the plant-soil feedback (Van der Putten et al., 2013; Brandt et al., 2013). Soil erosion is a key process in redistributing the soil particles, the seeds, and the nutrients (Cerdà and Lasanta, 2005; Lasanta and Cerdà, 2005). Fire may alter physicochemical soil properties (i.e., soil organic matter content and structure, hydrophobicity, $\mathrm{pH}$ and nutrient cycles) and microbiological or biochemical soil properties (i.e., microbial biomass, microbial activity, soil enzymes activities) (Mataix-Solera et al., 2009). These changes mostly occur below $5 \mathrm{~cm}$ of the surface, where the soil temperature rarely overtakes $100^{\circ} \mathrm{C}$ (Úbeda and Outeiro, 2009; Aznar et al., 2013). Post-fire silvicultural treatments may also modify the soil microbiological and biochemical variables, such as belowground biological activity and soil nutrients' availability (Grady and Hart, 2006) or enzyme activities (Wic-Baena et al., 2013). Tree felling or shrub clearing modifies microclimatic conditions at the ground level, as well as the amount and quality of potential organic inputs to soil (Grady and Hart, 2006). The magnitude of the changes occurring after wildfire events or post-fire silvicultural treatments depends on forest characteristics, such as the recovery capacity of vegetation (Irvine et al., 2007), climatic factors (Almagro et al., 2009) and post-fire soil rehabilitation management (Fernández et al., 2012; Prats et al., 2013).

Given the fundamental importance of soil microbial communities in soil ecosystem sustainability, information on how microbial functionality is affected by fire or post-fire silvicultural treatments under semiarid climatic conditions is required. Estimation of microbiota and soil status are necessary to determine optimal management strategies (Mabuhay et al., 2003; Mataix-Solera et al., 2009). In this context, the use of one parameter is not consistent because soil quality depends on a wide range of chemical, physical, biochemical and microbiological variables (Nannipieri et al., 1990; Bastida et al., 2008b). Thus, many authors have proposed using a combination of several variables as indicators of soil status (Dick et al., 1996). Specific indicators of microbial activity, such as variables relating to nutrient cycles (nitrogen, carbon and phosphorus) and enzymatic activities (urease, $\beta$ glucosidase and phosphatase), have been proposed to evaluate soil status (Trasar-Cepeda et al., 1998). Moreover, general indicators of microbial activity have been extensively used in forest and agricultural soil status characterisation (Armas et al., 2007; García-Orenes et al., 2010; Fterich et al., 2014; Ferreira et al., 2014).

Long-term studies into soil quality or those that evaluate soil recovery capacity are scarce. However, long term studies are necessary to reach reasonable conclusions on the impacts that fire events and post-fire silvicultural treatments have on soil properties, particularly in Mediterranean ecosystems (Wic-Baena et al., 2013). Some long-term studies appreciated that soil organic matter and microbial communities can recover to the pre-fire levels in the Mediterranean region, taking into account study areas dominated by Quercus ilex L., Quercus suber L. and Pinus pinaster Aiton subsp. pinaster (Guénon et al., 2013). The aim of this study is to investigate soil microbiological and soil enzymatic activities in different semiarid and dry Aleppo pine forest ecosystems affected by the following: (i) a wildfire event occurred 17 years ago; (ii) a wildfire event 17 years ago and treated with early thinning 12 years earlier; (iii) an Aleppo pine in a mature stand not affected by wildfire with no silvicultural treatments. We hypothesised the following: (1) that microbiological soil properties and enzymatic activities are influenced by the climatic conditions recorded at each semiarid and dry location; (2) that microbiological soil properties and enzymatic activities recover after the wildfire and the thinning at the mid-term.

\section{Material and methods}

\subsection{Study area}

The study was conducted at two sites burnt in the summer of 1994, Yeste and Calasparra (in the provinces of Albacete and Murcia, respectively) in SE Spain. The total burnt area covered about 44000 ha in both provinces. The forest tree composition in the study area was dominated by mature evenaged Aleppo pine stands, with shrubs and herbaceous vegetation in the understory (Table 1). Natural post-fire regeneration took place at both sites (45 000 saplings ha $^{-1}$ in Calasparra and 7000 saplings ha $^{-1}$ in Yeste) (Table 1). The climate of both experimental areas is classified as Mediterranean (Allué, 1990), with Yeste and Calasparra classed as a dry site and a semi-arid ombroclimate site, respectively (Rivas Martínez, 1987). Average annual rainfall and temperature for the last 30 years were respectively $503 \mathrm{~mm}$ and $13.5^{\circ} \mathrm{C}$ in Yeste as compared to $282 \mathrm{~mm}$ and $16.3^{\circ} \mathrm{C}$ in Calasparra. According to the Spanish Soil Map (Guerra Delgado, 1968), Yeste and Calasparra soils are classified as Inceptisols and Aridisols, respectively (Table 1). Soil texture at both sites is classified as loam/clay loam (Table 1).

\subsection{Experimental design}

Two experimental sites of 3 ha were selected in both Yeste $\left(2^{\circ} 20^{\prime} \mathrm{W} 38^{\circ} 21^{\prime} \mathrm{S}\right)$ and Calasparra $\left(1^{\circ} 38^{\prime} \mathrm{W} 38^{\circ} 16^{\prime} \mathrm{S}\right)$. Three plots were set up inside each site, one of which (1 ha) was naturally burnt in summer 1994 and was then occupied by 
Table 1. Soil, climatic and stand characteristics of each experimental site ${ }^{\mathrm{a}}$.

\begin{tabular}{|c|c|c|c|c|c|c|c|c|c|}
\hline Site & $\begin{array}{l}\text { Exp. } \\
\text { condition }\end{array}$ & $\begin{array}{l}\text { Altitude } \\
\text { (ma.s.l.) }\end{array}$ & $\begin{array}{l}\text { Vegetation } \\
\text { cover }^{\mathrm{a}}\end{array}$ & $\begin{array}{c}\text { Aleppo } \\
\text { pine } \\
\text { density } \\
\text { (trees ha } \\
\text { (t) })\end{array}$ & $\begin{array}{c}T \\
\left({ }^{\circ} \mathrm{C}\right)\end{array}$ & $\begin{array}{c}H \\
(\%)\end{array}$ & $\begin{array}{l}\text { Mean } \\
\text { age } \\
\text { (years) }\end{array}$ & $\begin{array}{l}\text { Shrub and herbaceous } \\
\text { vegetation }\end{array}$ & $\begin{array}{l}\text { Soil order } \\
\text { (suborder)/texture }\end{array}$ \\
\hline \multirow{3}{*}{ Calasparra } & MAT & 330 & $\begin{array}{l}90 \% \mathrm{Ph} \\
10 \% \text { Shrub } \\
\text { and herbaceous }\end{array}$ & 400 & $12.0 \pm 1.1$ & $5.9 \pm 2.0$ & $70-80$ & $\begin{array}{l}\text { Macrochloa tenacissima (L.) Kunth; } \\
\text { Rosmarinus officinalis }\end{array}$ & $\begin{array}{l}\text { Aridisol (Orthid) } \\
\text { loam }\end{array}$ \\
\hline & BNOT & 430 & $\begin{array}{l}80 \% \mathrm{Ph} \\
20 \% \text { Shrub } \\
\text { and herbaceous }\end{array}$ & 45000 & $9.2 \pm 1.8$ & $7.5 \pm 1.1$ & 17 & $\begin{array}{l}\text { Macrochloa tenacissima (L.) Kunth; } \\
\text { Rosmarinus officinalis; } \\
\text { Brachypodium retusum; } \\
\text { Thymus vulgaris L. }\end{array}$ & $\begin{array}{l}\text { Aridisol (Orthid) } \\
\text { loam }\end{array}$ \\
\hline & BT & 330 & $\begin{array}{l}70 \% \mathrm{Ph} \\
30 \% \text { Shrub } \\
\text { and herbaceous }\end{array}$ & 1600 & $9.5 \pm 1.4$ & $5.2 \pm 0.9$ & 17 & $\begin{array}{l}\text { Macrochloa tenacissima }(\mathrm{L} .) \text { Kunth; } \\
\text { Rosmarinus officinalis } \\
\text { Brachypodium retusum; } \\
\text { Thymus vulgaris L. }\end{array}$ & $\begin{array}{l}\text { Aridisol (Orthid) } \\
\text { loam }\end{array}$ \\
\hline \multirow{3}{*}{ Yeste } & MAT & 1010 & $\begin{array}{l}90 \% \mathrm{Ph} \\
10 \% \text { Shrub } \\
\text { and herbaceous }\end{array}$ & 500 & $8.0 \pm 1.2$ & $10.6 \pm 1.8$ & $70-80$ & $\begin{array}{l}\text { Rosmarinus officinalis L., } \\
\text { Brachypodium retusum }\end{array}$ & $\begin{array}{l}\text { Inceptisol (Ochrept) } \\
\text { loam }\end{array}$ \\
\hline & BNOT & 860 & $\begin{array}{l}80 \% \mathrm{Ph} \\
20 \% \text { Shrub } \\
\text { and herbaceous }\end{array}$ & 7000 & $7.1 \pm 0.9$ & $14.6 \pm 3.1$ & 17 & $\begin{array}{l}\text { Rosmarinus officinalis L., } \\
\text { Brachypodium retusum }\end{array}$ & $\begin{array}{l}\text { Inceptisol (Ochrept) } \\
\text { loam }\end{array}$ \\
\hline & BT & 1010 & $\begin{array}{l}70 \% \mathrm{Ph} \\
30 \% \text { Shrub } \\
\text { and herbaceous }\end{array}$ & 1600 & $7.5 \pm 1.3$ & $12.4 \pm 2.6$ & 17 & $\begin{array}{l}\text { Rosmarinus officinalis L., } \\
\text { Brachypodium retusum }\end{array}$ & $\begin{array}{l}\text { Inceptisol (Ochrept) } \\
\text { clay loam }\end{array}$ \\
\hline
\end{tabular}
a Ph: Aleppo pine; $T$ : soil temperature (mean \pm standard error) during the sampling period; $H$ : soil and stand characteristics of each experimental site (mean \pm standard error) during the season of sampling.
b Soil taxonomy (USDA).

high Aleppo pine post-fire natural. The second plot of 1 ha was naturally burnt in summer 1994 and then thinned in 1999. The post-fire silvicultural treatment and thinning operations left 1600 saplings ha $^{-1}$ at both the Calasparra and Yeste sites. The third plot was a mature stand of 1 ha used as a control. The mature Aleppo pine stand was located adjacent to the fire perimeter at both the Calasparra and Yeste sites and has not been affected by either forest-fire or silvicultural treatments in the last 20 years. It is noteworthy that we define recovery as a scenario which returns to the same soil functioning activity levels between the burnt or thinned and mature plots. All the plots were selected in areas with a low slope $(<5 \%)$. Sampling was carried out in early winter as Ferguson et al. (2007) recommended in their guidelines for soil sampling.

In December 2011, six soil samples $(1000 \mathrm{~g})$ were randomly taken from each plot: (i) the plot affected by a wildfire event and post-fire silvicultural treatments 17 and 12 years earlier, respectively (burned and thinned, hereafter named "BT"); (ii) the plot affected by a wildfire event 17 years earlier with no post-fire silvicultural treatments (burned and not thinner, hereafter named "BNOT"); (iii) the plot occupied by a mature Aleppo pine stand (hereafter named "MAT"). Each soil sample was composed of six subsamples collected in a $5 \mathrm{~m} \times 5 \mathrm{~m}$ subplot area, which were thoroughly mixed to obtain a composite sample (Andrés Abellan et al., 2011). Finally 36 samples were obtained: 2 experimental sites $x$ 3 treatments $\times 6$ replicates. The results shown are the average of the samples taken at each subplot. Soil samples were taken from the uppermost mineral layer $(0-15 \mathrm{~cm})$ after removing litter. Samples were passed through a $2 \mathrm{~mm}$ sieve and were kept at $4{ }^{\circ} \mathrm{C}$ for 1 month to avoid any influence on the parameters analysed in the laboratory (Andrés Abellan et al., 2011).

\subsection{Physical and chemical variables}

A total of $500 \mathrm{~g}$ of the collected soil samples were used to analyse some physical and chemical soil properties. $\mathrm{pH}$ and electrical conductivity (EC) were measured in a $1 / 5(w / v)$ aqueous solution using a pH-meter (Navi Horiba model). Total organic carbon (TOC) was determined by wet oxidation with $\mathrm{K}_{2} \mathrm{CrO}_{7}$ and titration of dichromate excess with Mohr's salt (Yeomans and Bremner, 1989), while organic matter $(\mathrm{OM})$ was inferred by multiplying the TOC content by 1.728 (Lucas-Borja et al., 2010b). Total carbonates $\left(\mathrm{CO}_{3}^{2-}\right)$ were measured in a Bernard calcimeter according to the method of Guitián and Carballas (1976). Bioavailable phosphorus $(\mathrm{P})$ was determined using the method described by Olsen and Sommers (1982). Total nitrogen (total N) was measured following Kjeldhal's method modified by Bremner (1965). The texture analysis was performed using the method of Guitián and Carballas (1976). Soil moisture and temperatures were recorded during the sampling season (winter 2011) using a soil moisture sensor (ECHO EC-10 model), a soil temperature sensor (TMC6-HD model) and a data-logger (Hobo U12-006 model). Soil temperature and humidity sensors were installed at a depth of $10 \mathrm{~cm}$ in each plot. 


\subsection{Biochemical and microbiological variables}

Soil dehydrogenase activity (DHA) was determined by using $1 \mathrm{~g}$ of soil, and the reduction of p-iodonitrotetrazolium chloride (INT) to p-iodonitrotetrazolium formazan was measured by a modified version of the method reported by García et al. (1993). Soil dehydrogenase activity was expressed as $\mu \mathrm{mol} \mathrm{INTFg}^{-1} \mathrm{soil} \mathrm{h}^{-1}$. Urease activity (UA) was determined as the $\mathrm{NH}_{4}^{+}$released in the hydrolysis reaction (Kandeler et al., 1999). Alkaline phosphatase (PA) and $\beta$ glucosidase (BA) activities were measured following the methods reported by Tabatabai and Bremner (1969) and Tabatabai (1982), respectively. Basal soil respiration (RESP) was analysed by placing 50 of soil moistened to 40-50\% of its water-holding capacity (water potential: $0.055 \mathrm{MPa}$ ) in hermetically sealed flasks and by incubating for 20 days at $28^{\circ} \mathrm{C}$. Released $\mathrm{CO}_{2}$ was periodically measured (daily for the first 4 days and then weekly) using an infrared gas analyzer (Toray PG-100, Toray Engineering Co. Ltd., Japan). The data were summed to give a cumulative amount of released $\mathrm{CO}_{2}$ after a 20-day incubation. Basal soil respiration was expressed as $\mathrm{mgCO}_{2-} \mathrm{C} \mathrm{kg}^{-1}$ soil per day. Microbial biomass carbon (CB) was determined by Vance et al. (1987) following the method adapted by García et al. (2003).

\subsection{Statistical analysis}

Data were analysed by a two-way analysis of variance (ANOVA) at which site level (Yeste and Calasparra) and the silvicultural management level ("BT", "MAT" and "BNOT") were selected as the factors. All the subplots were assumed to be spatially independent. The post hoc test applied was Fisher's least significant difference. A $P<0.05$ level of significance was adopted throughout, unless otherwise stated.

Moreover, a multivariate statistical method using a principal component analysis (PCA) was carried out to study the structure of the dependence and correlation between the physicochemical and microbiological soil properties at the different sites and for the various treatments. Another multivariate statistical method (correlation analysis) was carried out. To satisfy the assumptions of the statistical test (equality of variance and normal distribution), variables were squareroot transformed whenever necessary. The statistical analyses were done with the Statgraphics Centurion software.

\section{Results}

\subsection{Physical and chemical variables}

Soil temperature and soil moisture differed significantly $(P<0.05)$ between both experimental sites (Yeste and Calasparra), but not between different treatments ("BT", "MAT" and "BNOT") (Table 1). Soil texture (Table 1) and electrical conductivity (Table 2) were similar for both study sites and for the different treatments. The percentage of car- bonates, organic matter, phosphorus and total nitrogen differed between sites, with higher values recorded for Yeste. Significant differences were also observed $(P<0.05)$ in the $\mathrm{pH}$ values and $\mathrm{C} / \mathrm{N}$ ratio between sites, with Yeste obtaining lower values. Under the experimental conditions ("BT", "MAT" and "BNOT"), the physical and chemical variables showed a different behaviour depending on the site (Yeste and Calasparra; Table 2). There were not significant differences in any of the studied parameters taking into account the interaction.

\subsection{Biochemical and microbiological variables}

The experimental treatments considered in this study and the interaction between sites and experimental treatments did not significantly $(P<0.05)$ influence the microbiological properties and enzyme activities (Table 3, Figs. 1 and $2)$. The experimental site was the only influential factor $(P<0.05)$ found for microbial biomass carbon, soil respiration and enzymatic activities (Table 3). Urease activity showed higher values in Calasparra than in Yeste, whereas $\beta$-glucosidase and dehydrogenase activities displayed higher values in Yeste than in Calasparra (Fig. 1). No significant differences for phosphatase activity were found (Fig. 1).

\subsection{Correlation analysis}

Positive and significant correlation coefficients were found between organic matter and some microbiological and biochemical variables (dehydrogenase, $\beta$-glucosidase and soil respiration). Negative and significant correlation coefficients were observed between organic matter and the physicalchemical variables, such as $\mathrm{pH}$ and $\mathrm{C} / \mathrm{N}$ ratio and with the urease activity (Table 4). $\mathrm{pH}$ also showed a positive correlation and a significant coefficient with urease activity. $\mathrm{pH}$ negatively and significantly correlated with soil respiration, dehydrogenase and $\beta$-glucosidase activity. Urease activity presented different correlation coefficients, and positively and significantly correlated with phosphatase activity, $\mathrm{pH}$ and $\mathrm{C} / \mathrm{N}$ ratio, while a negative and significant correlation was observed with dehydrogenase and $\beta$-glucosidase activities and total carbonates, phosphorus and total nitrogen. Conversely, a positive and significant correlation was seen between dehydrogenase and $\beta$-glucosidase activity. $\mathrm{pH}$ and $\mathrm{C} / \mathrm{N}$ ratio correlated significantly and negatively with dehydrogenase and $\beta$-glucosidase activities (Table 4 ).

\subsection{PCA analysis}

The multivariate PCA analysis showed differences between the two study sites by separating into homogeneous groups (Fig. 3). Conversely, the PCA did not separate among different treatments. The PCA analysis clustered the plots located in Yeste on the negative axis of PC 2 (Fig. 3), which explained about $13.81 \%$ of variability. PC 1 explained around $42.22 \%$ of variability. The plots located in Calasparra were 
Table 2. Soil physicochemical parameters for each site and experimental condition.

\begin{tabular}{|c|c|c|c|c|c|c|c|c|}
\hline \multirow[t]{2}{*}{ Site } & \multirow[t]{2}{*}{ Exp. condition } & \multirow[t]{2}{*}{$\mathrm{pH}$} & \multirow{2}{*}{$\begin{array}{l}\text { Electrical conductivity } \\
\left(\mu \mathrm{S} \mathrm{cm}^{-1}\right)\end{array}$} & Organic matter & Total carbonates & \multirow{2}{*}{$\begin{array}{l}P \\
\left(\mathrm{mgkg}^{-1}\right)\end{array}$} & \multirow{2}{*}{$\begin{array}{l}\text { Total N } \\
(\%)\end{array}$} & \multirow[t]{2}{*}{$\mathrm{C} / \mathrm{N}$} \\
\hline & & & & \multicolumn{2}{|c|}{$(\%)$} & & & \\
\hline \multirow{3}{*}{ Calasparra } & $\mathrm{BT}$ & $8.66(0.07) \mathrm{aA}$ & $21.15(0.78) \mathrm{aA}$ & $6.73(0.66) \mathrm{aB}$ & $2.72(0.07) \mathrm{aB}$ & $11.32(1.35) \mathrm{aB}$ & $0.18(0.00) \mathrm{aB}$ & $53.5(4.26) \mathrm{bA}$ \\
\hline & BNOT & $8.75(0.06) \mathrm{aA}$ & $20.28(1.03) \mathrm{aA}$ & $5.87(0.38) \mathrm{bB}$ & $2.13(0.02) \mathrm{bB}$ & $12.74(3.84) \mathrm{aB}$ & $0.11(0.00) \mathrm{bB}$ & $83(5.95) \mathrm{aA}$ \\
\hline & MAT & $8.39(0.02) \mathrm{bA}$ & 23.48 (2.69) aA & $5.35(0.68) \mathrm{bB}$ & $1.92(0.20) \mathrm{bB}$ & $16.95(1.12) \mathrm{aB}$ & $0.20(0.03) \mathrm{aB}$ & $44(3.73) \mathrm{bA}$ \\
\hline \multirow{3}{*}{ Yeste } & $\mathrm{BT}$ & $8.30(0.17) \mathrm{aB}$ & $20.85(0.02) \mathrm{aA}$ & $8.24(0.60) \mathrm{aA}$ & $2.94(0.01) \mathrm{aA}$ & $27.99(0.57) \mathrm{aA}$ & $0.98(0.22) \mathrm{aA}$ & $16.5(4.22) \mathrm{aB}$ \\
\hline & BNOT & $7.83(0.17) \mathrm{aB}$ & $21.15(0.73) \mathrm{aA}$ & $9.17(0.19) \mathrm{aA}$ & $2.94(0.01) \mathrm{aA}$ & $14.24(2.38) \mathrm{cA}$ & $1.09(0.26) \mathrm{aA}$ & $15(3.71) \mathrm{aB}$ \\
\hline & MAT & $8.37(0.22) \mathrm{aB}$ & $21.89(2.28) \mathrm{aA}$ & $6.42(0.22) \mathrm{bA}$ & $2.88(0.02) \mathrm{bA}$ & 20.63 (2.67) bA & $0.76(0.27) \mathrm{aA}$ & $33(12.07) \mathrm{aB}$ \\
\hline
\end{tabular}

For each parameter, values represent mean (standard error). Data followed by the same small letter are not significantly different according to the Fisher's Least Significant Difference (LSD) test $(P<0.05)$ for each experimental condition. For each experimental site, data followed by the same capital letter are not significantly different according to the LSD test $(P<0.05)$

Table 3. Result of the two-factor ANOVA (site and experimental condition) for the microbiological properties and enzymatic activities analysis.

\begin{tabular}{|c|c|c|c|c|c|c|c|c|c|c|c|c|}
\hline \multirow[t]{2}{*}{ Factors } & \multicolumn{2}{|c|}{ Dehydrogenase activity } & \multicolumn{2}{|c|}{ Urease activity } & \multicolumn{2}{|c|}{ Phosphatase activity } & \multicolumn{2}{|c|}{$\beta$-glucosidase activity } & \multicolumn{2}{|c|}{ Basal respiration } & \multicolumn{2}{|c|}{ Microbial biomass carbon } \\
\hline & $F$ ratio & $p$ value & $F$ ratio & $p$ value & $F$ ratio & $p$ value & $F$ ratio & $p$ value & $F$ ratio & $p$ value & $F$ ratio & $p$ value \\
\hline $\mathrm{S}$ & 170.21 & 0.0001 & 45.15 & 0.0001 & 0.37 & 0.5486 & 65.14 & 0.0001 & 14.88 & 0.0006 & 4.61 & 0.0399 \\
\hline $\mathrm{T}$ & 0.34 & 0.7137 & 0.01 & 0.9932 & 0.29 & 0.754 & 1.70 & 0.1993 & 1.35 & 0.274 & 0.20 & 0.8202 \\
\hline $\mathrm{S} \times \mathrm{T}$ & 2.16 & 0.1334 & 0.02 & 0.9819 & 0.05 & 0.9519 & 0.72 & 0.4948 & 0.01 & 0.9885 & 0.07 & 0.9363 \\
\hline
\end{tabular}

S: site; $\mathrm{T}$ : experimental treatment; $\mathrm{S} \times \mathrm{T}$ : interaction between $\mathrm{S}$ and $\mathrm{T}$.
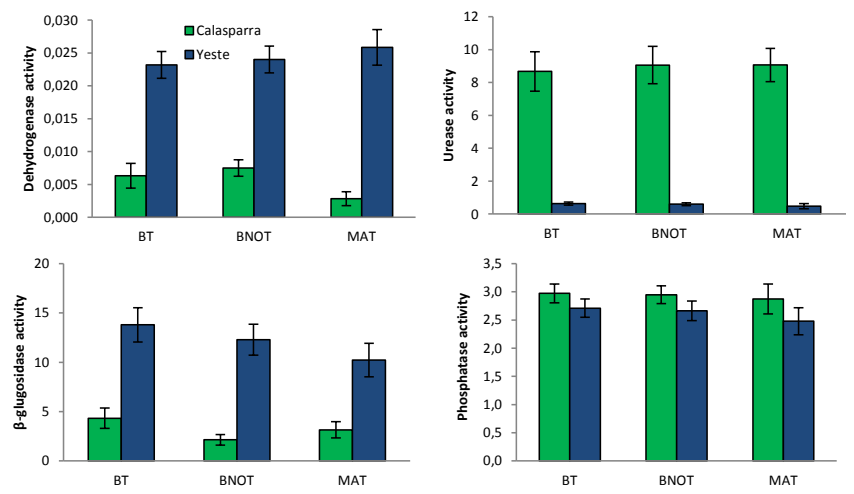

Figure 1. Dehydrogenase activity $\left(\mu \mathrm{g}(\mathrm{INTF}) \mathrm{g}^{-1}\right.$ soil $\left.^{-1}\right), \beta$ glucosidase activity $\left(\mu \mathrm{molPNPg} \mathrm{P}^{-1} \mathrm{dry} \mathrm{soilh}^{-1}\right)$, phosphatase activity $\left(\mu \mathrm{molPNPg}{ }^{-1}\right.$ dry soil $\left.^{-1}\right)$ and urease activity $(\mu \mathrm{molN}$ $\mathrm{NH}_{4}^{+} \mathrm{g}^{-1}$ dry soil ${ }^{-1}$ ) in relation to the experimental site. Error bars are the LSD intervals at $P<0.05$.

clustered on the positive axis of PC 2. Urease activity, $\mathrm{C} / \mathrm{N}$ ratio and $\mathrm{pH}$ had a positive weight on $\mathrm{PC} 1$, whereas dehydrogenase, $\beta$-glucosidase and organic matter had a negative weight (Table 5). Moreover, respiration, phosphatase and electrical conductivity had a positive weight on PC 2, while phosphorus and biomass carbon had a negative weight. The other loading factors of the different variables appear in Table 5.
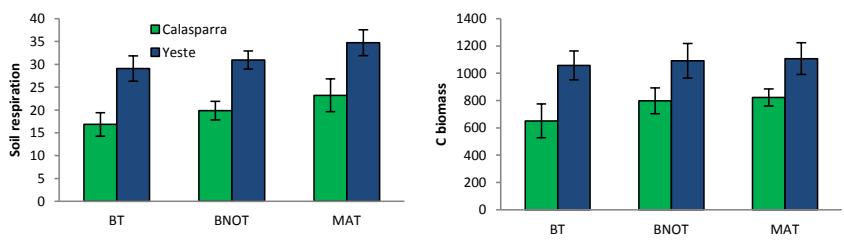

Figure 2. Basal soil respiration $\left(\mathrm{mg} \mathrm{CO}_{2} \mathrm{~kg}^{-1}\right.$ soil) and microbial biomass carbon $\left(\mathrm{mg} \mathrm{kg}^{-1}\right)$ in relation to the experimental site. Error bars are the LSD intervals at $P<0.05$.

\section{Discussion}

Vegetation and soil type are key factors that can modify soil characteristics and are responsible for maintaining a stable microbial community (Bastida et al., 2008a). Since Aleppo pine forest dominates both experimental sites, variations in soil properties can be related mainly to site-specific differences, such as soil temperature and moisture and soil type (soil organic matter, $\mathrm{C} / \mathrm{N}$ ratio, $\mathrm{pH}$ and $\mathrm{P}$, soil texture). Micro-climatic factors influence microbial enzymes, and also change the quality and quantity of the substrate upon which they act (Kumar et al., 1992). Different authors have demonstrated that scarce soil moisture generate lower soil respiration rates, microbial biomass carbon values and dehydrogenase, phosphatase and $\beta$-glucosidase enzymatic activities (Criquet et al., 2004; Sardans and Peñuelas, 2005; Baldrian et al., 2010; Lucas-Borja et al., 2012). Our results coincide with these trends since Calasparra (higher temperatures at lower soil moisture values) obtained lower values of microbiological parameters, $\beta$-glucosidase and dehydrogenase activities, but higher values for urease and phosphatase enzymes. The 
Table 4. Correlation matrix between the different variables determined.

\begin{tabular}{|c|c|c|c|c|c|c|c|c|c|c|c|c|c|}
\hline & UA & PA & DHA & BA & $\mathrm{BC}$ & RESP & $H$ & $\mathrm{OM}$ & $\mathrm{P}$ & $\mathrm{pH}$ & EC & Total N & $\mathrm{CO}_{3}^{2-}$ \\
\hline PA & $0.38^{*}$ & - & - & - & - & - & - & - & - & - & - & - & - \\
\hline DHA & $-0.66^{* * *}$ & $-0.14 \mathrm{~ns}$ & - & - & - & - & - & - & - & - & - & - & - \\
\hline BA & $-0.58^{* * *}$ & $-0.06 \mathrm{~ns}$ & $0.67^{* * * *}$ & - & - & - & - & - & - & - & - & - & - \\
\hline $\mathrm{CB}$ & $-0.26 \mathrm{~ns}$ & $-0.11 \mathrm{~ns}$ & $0.36^{*}$ & $0.28 \mathrm{~ns}$ & - & - & - & - & - & - & - & - & - \\
\hline RESP & $-0.12 \mathrm{~ns}$ & $0.18 \mathrm{~ns}$ & $0.61^{* * *}$ & $0.42^{*}$ & $0.10 \mathrm{~ns}$ & - & - & - & - & - & - & - & - \\
\hline$H$ & $-0.62^{* * *}$ & $0.01 \mathrm{~ns}$ & $0.77^{* * *}$ & $0.76^{* * *}$ & $0.28 \mathrm{~ns}$ & $0.41^{*}$ & - & - & - & - & - & - & - \\
\hline $\mathrm{OM}$ & $-0.38^{*}$ & $0.18 \mathrm{~ns}$ & $0.50^{* *}$ & $0.56^{* * *}$ & $0.02 \mathrm{~ns}$ & $0.54^{* * *}$ & $0.47^{* *}$ & - & - & - & - & - & - \\
\hline $\mathrm{P}$ & $-0.41^{*}$ & $-0.13 n s$ & $0.26 \mathrm{~ns}$ & $0.52^{* *}$ & $0.19 \mathrm{~ns}$ & $0.10 \mathrm{~ns}$ & $0.43^{* *}$ & $0.11 \mathrm{~ns}$ & - & - & - & - & - \\
\hline $\mathrm{pH}$ & $0.39^{*}$ & $-0.15 n s$ & $-0.39^{*}$ & $-0.57^{* * *}$ & $-0.19 \mathrm{~ns}$ & $-0.40^{*}$ & $-0.50^{*}$ & $-0.63^{* * *}$ & $-0.11 \mathrm{~ns}$ & - & - & - & - \\
\hline $\mathrm{EC}$ & $0.18 \mathrm{~ns}$ & $0.10 \mathrm{~ns}$ & $0.10 \mathrm{~ns}$ & $-0.13 n s$ & $-0.03 \mathrm{~ns}$ & $0.43^{* *}$ & $-0.09 \mathrm{~ns}$ & $0.07 \mathrm{~ns}$ & $-0.16 n s$ & $0.16 \mathrm{~ns}$ & - & - & - \\
\hline Total N & $-0.51^{* *}$ & $-0.07 \mathrm{~ns}$ & $0.73^{* * *}$ & $0.54^{* * *}$ & $0.35^{*}$ & $0.64 *$ & $0.62^{* * *}$ & $0.27 \mathrm{~ns}$ & $0.06 \mathrm{~ns}$ & $-0.21 \mathrm{~ns}$ & $0.33^{*}$ & - & - \\
\hline $\mathrm{CO}_{3}^{2-}$ & $-0.58^{* * *}$ & $-0.06 \mathrm{~ns}$ & $0.61^{* * *}$ & $0.58^{* * *}$ & $0.27 \mathrm{~ns}$ & $0.45^{* *}$ & $0.46^{* *}$ & $0.38^{*}$ & $0.30 \mathrm{~ns}$ & $-0.63^{* * *}$ & $-0.26 \mathrm{~ns}$ & $0.20 \mathrm{~ns}$ & - \\
\hline $\mathrm{C} / \mathrm{N}$ & $0.50^{* *}$ & $0.12 \mathrm{~ns}$ & $-0.67^{* * *}$ & $-0.55^{* * *}$ & $-0.27 \mathrm{~ns}$ & $-0.41^{*}$ & $-0.57^{* * *}$ & $-0.33^{*}$ & $-0.27 \mathrm{~ns}$ & $0.25 \mathrm{~ns}$ & $-0.40^{*}$ & $-0.82^{* * *}$ & $-0.26 \mathrm{~ns}$ \\
\hline
\end{tabular}

UA: urease activity; PA: phosphatase activity; DHA: Dehydrogenase activity; BA: $\beta$-Glucosidase activity; CB: biomass carbon; RESP: soil respiration; $H$ : soil moisture; OM: organic matter; P: phosphorus, pH; CE: electrical conductivity; Total N: total nitrogen; $\mathrm{CO}_{3}^{2-}$ : total carbonates; $\mathrm{C} / \mathrm{N}$ : carbon nitrogen ratio. Significant correlations: ${ }^{*} P \leq 0.05 ;{ }^{* *} P \leq 0.01$; ${ }^{* * *} P \leq 0.001$; ns: non-significant.

Table 5. Weights of principal components analysis.

\begin{tabular}{lrr}
\hline & PC 1 & PC 2 \\
\hline Dehydrogenase & -0.351 & -0.072 \\
$\beta$-glucosidase & -0.341 & -0.092 \\
Moisture & -0.334 & -0.103 \\
Organic matter & -0.283 & 0.359 \\
Total nitrogen & -0.273 & -0.079 \\
Soil respiration & -0.247 & 0.338 \\
Phosphorus & -0.161 & -0.298 \\
Carbon biomass & -0.143 & -0.271 \\
Electrical conductivity & -0.021 & 0.317 \\
Phosphatase & 0.017 & 0.444 \\
pH & 0.264 & -0.168 \\
Total carbonates & -0.271 & -0.093 \\
C/N & 0.284 & 0.058 \\
Urease & 0.288 & 0.312 \\
\hline
\end{tabular}

latter may be explained by quantity of total $\mathrm{N}$ and $\mathrm{P}$ present at each site. Given the lower total $\mathrm{N}$ and $\mathrm{P}$ values found in Calasparra, greater urease and phosphatase activity may be required to produce inorganic $\mathrm{N}$ and $\mathrm{P}$ ready for plant development. Gutknecht et al. (2010) showed that decreased N and $\mathrm{P}$ results in greater urease and phosphatase activity and higher enzyme production through soil microorganisms. On the other hand, Bastida et al. (2008a) indicated that seasonality affects enzymatic activities or microbial biomass, and in this work only we sampled in early winter, so it would be suitable to conduct sampling in different seasons.

In relation to fire and post-fire silvicultural treatments, soil moisture and temperature showed no significant differences between the "BT", "MAT" and "BNOT" plots, thus may largely explain similar microbiological parameters values and enzymatic activities. Moreover, Aleppo pine is a pyrophyte species that exhibits good post-fire natural regeneration; good post-fire seedling recruitment during the first growth season after the wildfire event (Leone et al., 2000)

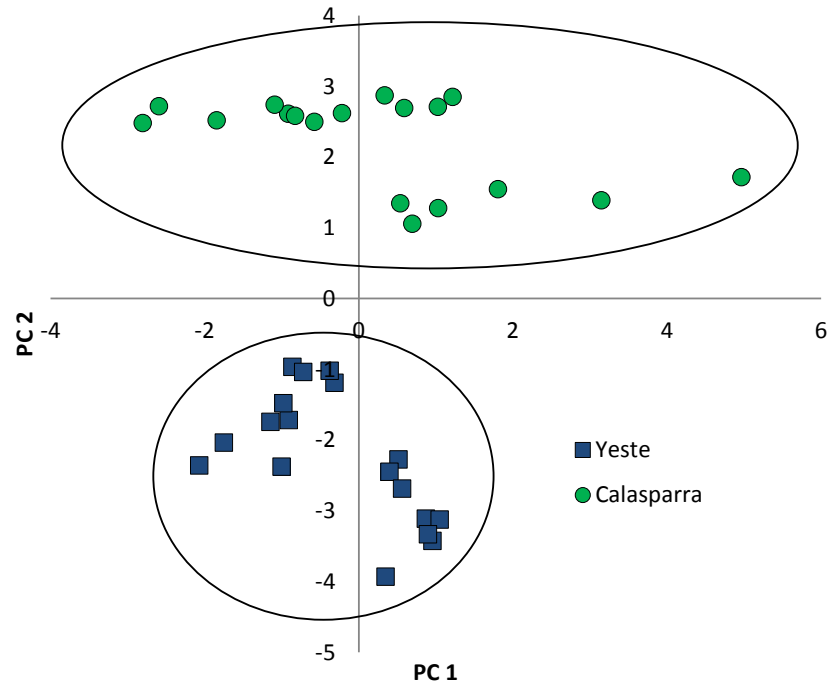

Figure 3. Principal components analysis of the experimental sites Yeste and Calasparra.

was observed. Thus, initial vegetation recovery is promptly ensured after a wildfire event (De las Heras et al., 2012). In this context, temporary plant-cover loss and subsequent plant recruitment after a fire event may enhance the recovery of microbiological soil properties. According to our results, the microbiological soil properties and enzymatic activities capacity recovery should be achieved 17 years after the wildfire event and the post-fire silvicultural treatment. This longterm study demonstrated that soil parameters might recover, at least, to the pre-fire levels 17 years after the fire event and thinning operations. Wic-Baena et al. (2013) have recently shown that soil enzymatic activities recovered 6 years after thinning. The same authors stated that the time period since the silvicultural treatment was applied seemed to significantly affect soil properties. It may be explained because long-term effects on soil processes are likely driven by changes in the quality of the organic matter inputs (Hart et 
al., 2005), and the relationship between post-fire recovery of Aleppo pine (dominant species in both experimental sites) and soil properties.

The organic matter greatly differed, obtaining higher values for Yeste than for Calasparra. Higher values for the general soil microbial activity indicators (i.e., soil respiration and dehydrogenase activity) and for $\beta$-glucosidase and phosphatase activity have been reported by Lucas-Borja et al. (2010a, 2011) in forest soil at a higher organic matter concentration. Some organic matter fractions contain readily metabolisable compounds, which can act as energy sources for microorganisms. In relation to fire and post-fire silvicultural treatments, the organic matter content was similar when comparing "BT", "MAT" and "BNOT" plots, which may be explained by the Aleppo pine post-fire initial recruitment. The organic matter derived from new trees may be responsible for the similarities comparing "BT", "MAT" and "BNOT" plots. We found significant positive correlations between microbiological measurements (soil respiration) and enzymatic activities (dehydrogenase and $\beta$-glucosidase activities) and organic matter content. Our results also indicate lower $\mathrm{C} / \mathrm{N}$ values at Yeste, but no significant differences among treatments, and we found significant negative correlations between microbiological measurements and enzymatic activities (except urease enzyme) with the $\mathrm{C} / \mathrm{N}$ ratio. As Merilä et al. (2002) have shown, substrate quality, as determined by $\mathrm{C} / \mathrm{N}$, generally influences microbial biomass and respiration, so the main substrate of the litterfall were pine needles, which have high content of lignin. Berg (1986) stated that higher $\mathrm{C} / \mathrm{N}$ ratios may be an indicator of the more recalcitrant nature of the soil organic matter. In Yeste and Calasparra, the Aleppo pine was the dominant species, so the main explanation of this different behaviour in each site may be the contrasting climatic conditions, which let the litterfall degrade faster. On the other hand, the experimental treatments showed the same climatic conditions and the same dominant tree species at each site, which can explain the absence of differences on $\mathrm{C} / \mathrm{N}$ values depending on the postfire treatment. Moreover, lower $\mathrm{C} / \mathrm{N}$ rates have been associated with higher respiration rates and microbiological properties (Schmitz et al., 1998).

Regarding $\mathrm{pH}$, some authors have denoted its influence on soil microbial biomass properties (Bååth and Anderson, 2003). According to Sinsabaugh et al. (2008), soil pH has direct biochemical effects on the activity of the extracellular enzymes immobilised in the soil matrix. The same author has also argued that soil $\mathrm{pH}$ reflects climatic controls in soil and plant community composition, which may affect the large-scale distribution of extracellular enzymatic activities through changes in nutrient availability, soil organic composition and microbial community composition. Our results agree with this trend and indicate that $\mathrm{pH}$ correlates negatively with soil enzyme activities (except urease activity), soil respiration and organic matter.
Finally, the PCA results reveal that the sites were significantly discriminated. The higher soil temperatures and lower soil moisture values recorded at Calasparra provide unfavourable conditions for balanced soil functional diversity, as reflected by poorer enzyme activities, soil respiration and biomass carbon if compared with Yeste. On the contrary, treatments were not significantly discriminated, which reflects that vegetation recovery after a wild-fire event and the time elapsed since the post-silvicultural treatments applied were enough to achieve the initial soil property values found in mature and unaffected plots.

\section{Conclusions}

Biochemical, microbiological and physicochemical variables are affected by site, but not by post-fire silvicultural treatment, under dry and semiarid conditions. A total of 17 years after the wildfire event and the post-fire silvicultural treatment, microbiological soil properties may recover the initial status and values shown for mature and undisturbed Aleppo pine forest stands. The micro-climatic conditions, higher soil temperature and lower soil moisture values obtained at Calasparra indicate unfavourable conditions for microbiological properties and enzyme activities if compared with Yeste. Our results provide data on the long-term recovery pattern of microbiological and enzymatic activities, and clearly distinguish between sites with different microclimatic conditions (temperature and moisture), but not among burnt/unburnt or post-fire thinned/unthinned Aleppo pine forests stands for more than 17 years after the wildfire and silvicultural treatment. Forest management guidelines should consider that forest site plays an important role in forest recovery after wildfire, and therefore in soil quality. Thus, forest management policies should take these aspects into account when designing (and budgeting) restoration plans.

Acknowledgements. The authors thank the Agencia Estatal de Meteorología (AEMET) for climatic data. We thank Helen Warburton for reviewing the English. The study has been funded by CONSOLIDER-INGENIO 2010: MONTES (CSD 2008-00040) of the Spanish Ministry of Science and Innovation.

Edited by: A. Jordán

\section{References}

Andrés Abellan, M., Wic Baena, C., García Morote, F., Picazo Córdoba, M., Candel Pérez, D., and Lucas-Borja, M.: Influence of the soil storage method on soil enzymatic activities, Forest Systems, 20, 379-388, 2011.

Allué, J. L.: Atlas Fitoclimático de España, Taxonomías, Instituto Nacional de Investigaciones Agrarias, Ministerio de Agricultura, Pesca y Alimentación, Madrid, 1990 (in Spanish). 
Almagro, M., López, J., Querejeta, J. I., and Martínez-Mena, M.: Temperature dependence of soil $\mathrm{CO}_{2}$ efflux is strongly modulated by seasonal patterns of moisture availability in a Mediterranean ecosystem, Soil Biol. Biochem., 41, 594-605, 2009.

Armas, C. M., Santana, B., Mora, J. L., Notario, J. S., Arbelo, C. D., and Rodríguez-Rodríguez, A.: A biological quality index for volcanic Andisols and Aridisols (Canary Islands, Spain): variations related to the ecosystem development, Sci. Total Environ., 378, 238-244, 2007.

Aznar, J. M., González-Pérez, J. A., Badía, D., and Martí, C.: At what depth are the properties of a gypseous forest topsoil affected by burning?, Land Degrad. Dev., doi:10.1002/ldr.2258, online first, 2013.

Bååth, E. and Anderson, T. H.: Comparison of soil fungal/bacterial ratios in a pH gradient using physiological and PLFA-based techniques, Soil Biol. Biochem., 35, 955-963, 2003.

Baldrian, P., Merhautová, V., Petránková, M., Cajthaml, T., Šnajdr, J.: Distribution of microbial biomass and activity of extracellular enzymes in a hardwood forest soil reflect soil moisture content, Appl. Soil Ecol., 46, 177-182, 2010.

Bastida, F., Barberá, G. G., García, C., and Hernández, T.: Influence of orientation, vegetation and season on soil microbial and biochemical characteristics under semiarid conditions, Appl. Soil Ecol., 38, 62-70, 2008a.

Bastida, F., Zsolnay, A., Hernández, T., and García, C.: Past, present and future of soil quality indices: A biological perspective, Geoderma, 147, 159-171, 2008b.

Berg, B.: Nutrient release from litter and humus in coniferous forest soils: a mini review, Scand. J. Forest Res., 1, 359-369, 1986.

Boydak, M., Dirik, H., and Çalıkoğlu, M.: Biology and silviculture of Turkish red pine Pinus brutia Ten., Laser Ofset Matbaa Tesisleri San. Tic. Ltd. Sti., Ankara, 2006.

Brandt, A. J., de Kroon, H., Reynolds, H. L., and Burns, J. H.: Soil heterogeneity generated by plant-soil feedbacks has implications for species recruitment and coexistence, J. Ecol., 101, 277-286, 2013.

Bremner, J. M.: Nitrogen availability indexes, in: Methods of Soil Analysis, Part 2, edited by: Black, C. A., American Society of Agronomy, Agronomy, 9, 1324-1345, 1965.

Cerdà, A. and Lasanta, A.: Long-term erosional responses after fire in the Central Spanish Pyrenees: 1. Water and sediment yield, Catena, 60, 59-80, 2005.

Criquet, S., Ferre, E., Farnet, A. M., and Le Petit, J.: Annual dynamics of phosphatase activities in an evergreen oak litter: Influence of biotic and abiotic factors, Soil Biol. Biochem., 36, 1111-1118, 2004.

De las Heras, J., Moya, D., Vega, J. A., Daskalakou, E., Vallejo, R., Grigoriadis, N., Tsitsoni, T., Baeza, J., Valdecantos, A., Fernandez, C., Espelta, J., and Fernandes, P.: Post-Fire Management of Serotinous Pine Forests, in: Post-Fire Management and Restoration of Southern European Forests, edited by: Moreira, F., Arianotsou, M., Corona, P., and De las Heras, J., Managing Forest Ecosystems, Springer, 24, 151-170, 2012.

Dick, R. P., Breakwell, D. P., and Turco, R. F.: Soil enzyme activities and biodiversity measurements as integrative microbiological indicators, in: Methods for assessing soil quality, edited by: Doran, J. W. and Jones, A. J., SSSA Special Publication 49, $247-$ 271,1996
Espelta, J. M., Verkaik, I., Eugenio, M., and Lloret, F.: Recurrent wildfires constrain long-term reproduction ability in Pinus halepensis Mill., Int. J. Wildland. Fire, 17, 579-585, 2008.

Ferguson, R. B., Hergert, G. W., Shapiro, C. S., and Wortmann, C. S.: Guidelines for Soil Sampling, NebGuide G1740, University of Nebraska-Lincoln, USA, 2007.

Fernández, C., Vega, J. A., Jiménez, E., Vieira, D. C. S., Merino, A., Ferreiro, A., and Fonturbel, T.: Seeding and mulching + seeding effects on post-fire runoff, soil erosion and species diversity in Galicia (NW Spain), Land Degrad. Dev., 23, 150-156, doi:10.1002/ldr.1064, 2012.

Ferreira, A. C. C., Leite, L. F. C., de Araújo, A. S. F., and Eisenhauer, N.: Land-use type effects on soil organic carbon and microbial properties in a semi-arid region of northeast Brazil, Land Degrad. Dev., doi:10.1002/ldr.2282, online first, 2014.

Fterich, A., Mahdhi, M., and Mars, M.: The effects of Acacia tortilis subsp. raddiana, soil texture and soil depth on soil microbial and biochemical characteristics in arid zones of Tunisia, Land Degrad. Dev., 25, 143-152, doi:10.1002/ldr.1154, 2014.

García, C., Hernández, T., Costa, F., Ceccanti, B., Masciandaro, G.: The dehydrogenase activity of soil as an ecological marker in processes of perturbed system regeneration, in: Proceedings of the XI International Symposium of Environmental Biochemistry, edited by: Gallardo-Lancho, J., CSIC, Salamanca, España, 89$100,1993$.

García, C., Gil, F., Hernández, M. T., and Trasar, C.: Técnicas de Análisis de Parámetros Bioquímicos en Suelos, Mundi-Prensa, Madrid, 2003 (in Spanish).

García-Orenes, F., Guerrero, C., Roldán, A., Mataix-Solera, J., Cerdà, A., Campoy, M., Zornoza, R., Bárcenas, G., and Caravaca, F.: Soil microbial biomass and activity under different agricultural management systems in a semiarid Mediterranean agroecosystem, Soil and Tillage Research, 109, 110-115, doi:10.1016/j.still.2010.05.005, 2010.

Grady, K. C. and Hart, S. C.: Influences of thinning, prescribed burning, and wildfire on soil processes and properties in southwestern ponderosa pine forests: a retrospective study, Forest Ecol. Manag., 234, 123-135, 2006.

Guénon, R., Vennetier, M., Dupuy, N., Roussos, S., Pailler, A., and Gros, R.: Trends in recovery of Mediterranean soil chemical properties and microbial activities after infrequent and frequent wildfires, Land Degrad. Dev., 24, 115-128, doi:10.1002/ldr.1109, 2013.

Guerra Delgado, A.: Leyenda del Mapa de Suelos de España (1:1.000.000), Instituto Nacional de Edafología, The Consejo Superior de Investigaciones Científicas (CSIC), Madrid, 1968 (in Spanish).

Guitián, F. and Carballas, T.: Técnicas de análisis de suelos, Pico Sacro, Santiago de Compostela, 1976 (in Spanish).

Gutknecht, J. L. M., Henry, H. A. L., and Balser, T. C.: Inter-annual variation in soil extra-cellular enzyme activity in response to simulated global change and fire disturbance, Pedobiologia, 53, 283293, 2010.

Hannam, K. D., Quideau, S. A., and Kishchuk, B. E.: Forest floor microbial communities in relation to stand composition and timber harvesting in northern Alberta, Soil Biol. Biochem., 38, 2565-2575, 2006 
Hart, S. C., DeLuca, T. H., Newman, G. S., MacKenzie, M. D., and Boyle, S. I.: Post-fire vegetative dynamics as drivers of microbial community structure and function in forest soils, Forest Ecol. Manag., 220, 166-184, 2005.

Irvine, J., Law, B. E., and Hibbard, K. A.: Postfire carbon pools and fluxes in semiarid ponderosa pine in Central Oregon, Glob. Change Biol., 13, 1748-1760, 2007.

Kandeler, E., Stemmer, M., and Klimanek, E.: Response of soil microbial biomass, urease and xylanase within particle size fractions to long-term soil management, Soil Biol. Biochem., 31, 261-273, 1999.

Kumar, J. D., Sharma, G. D., and Mishra, R. R.: Soil microbial population numbers and enzyme activities in relation to altitude and forest degradation, Soil Biol. Biochem., 24, 761-767, 1992.

Lasanta, A. and Cerdà, A.: Long-term erosional responses after fire in the Central Spanish Pyrenees: 2. Solute release, Catena, 60, 80-101, 2005.

Leone, V., Borghetti, M., and Saracino, A.: Ecology of post-fire recovery in Pinus halepensis in southern Italy, in: Life and Environment in Mediterranean Ecosystems, edited by: Trabaud, L., WIT Press, Southampton, 129-154, 2000.

Lucas-Borja, M. E., Bastida, F., Moreno, J. L., Nicolás, C., Andrés, M., and López, F. R.: The effects of human trampling on the microbiological properties of soil and vegetation in Mediterranean Mountain areas, Land Degrad. Dev., 22, 383-394, 2010a.

Lucas-Borja, M. E., Bastida, F., Nicolás, C., Moreno, J. L., Del Cerro, A., and Andrés, M.: Influence of forest cover and herbaceous vegetation on the microbiological and biochemical properties of soil under Mediterranean humid climate, Eur. J. Soil Biol., 46, 273-279, 2010b

Lucas-Borja, M. E., Candel, D., Jindo, K., Moreno, J. L., Andrés, M., and Bastida, F.: Soil microbial community structure and activity in monospecific and mixed forest stands, under Mediterranean humid conditions, Plant Soil, 354, 359-370, 2011.

Lucas-Borja, M. E., Candel, D., López-Serrano, F. R., Andrés, M., and Bastida, F.: Altitude-related factors but not Pinus community exert a dominant role over chemical and microbiological properties of a Mediterranean humid soil, Eur. J. Soil Sci., 63, 541-549, 2012.

Mabuhay, J. A., Nobukazu, N., and Horikoshi, T.: Microbial biomass and abundance after forest fire in pine forests in Japan, Ecol. Res., 18, 431-441, 2003.

Mataix-Solera, J., Guerrero, C., García-Orenes, F., Bárcenas, G. M., Torres, M. P., and Bárcenas, M.: Forest Fire Effects on Soil Microbiology, in: Fire Effects on Soils and Restoration Strategies Enfield, edited by: Cerdá, A. and Robichaud, P. R., Science Publishers, New Hampshire, 133-175, 2009.

Merilä, P., Smolander, A., and Strömmer, R.: Soil nitrogen transformations along a primary succession transect on the land-uplift coast in western Finland, Soil Biol. Biochem., 34, 373-385, 2002.

Moya, D., De las Heras, J., López-Serrano, F., and Leone, V.: A post-fire management model to improve Aleppo pine forest resilience, in: Modelling, monitoring and management of forest fires I, edited by: De las Heras, J., Brebbia, C. A., Viegas, D., and Leone, V., WittPress, Southhampton, 311-319, 2008.

Muscolo, A., Sidari, M., and Mercurio, R.: Influence of gap size on organic matter decomposition, microbial biomass and nutrient cycle in Calabrian pine (Pinus laricio, Poiret) stands, Forest Ecol. Manag., 242, 412-418, 2007.

Nannipieri, P., Grego, S., and Ceccanti, B.: Ecological significance of the biological activity in soil, in: Soil Biochemistry, edited by: Bollag, J. M. and Stotzky, G., Marcel Dekker, New York, 6, 293 355, 1990.

Olsen, S. R. and Sommers, L. E.: Phosphorus, in: Methods of Soil Analysis. Chemical and Microbiological Properties, 2nd Edn., edited by: Page, A. L., Miller, R. H., and Keeney, D. R., American Society of Agronomy, Madison, 403-427, 1982.

Pausas, J. G.: Changes in fire and climate in the eastern Iberian Peninsula (Mediterranean basin), Climatic Change, 63, 337-350, 2004.

Prats, S. A., Cortizo Malvar, M., Simões Vieira, D. C., MacDonald, L., and Keizer, J. J.: Effectiveness of hydromulching to reduce runoff and erosion in a recently burnt pine plantation in central Portugal, Land Degrad. Dev., doi:10.1002/ldr.2236, online first, 2013.

Rivas Martínez S.: Memoria del mapa de series de vegetación de España (1:400.000), ICONA, Ministerio de Agricultura, Pesca y Alimentación, Madrid, 1987 (in Spanish).

Rutigliano, F. A., Ascoli, R. D., and De Santo, A. V.: Soil microbial metabolism and nutrient status in a Mediterranean area as affected by plant cover, Soil Biol. Biochem., 36, 1719-1729, 2004.

Sardans, J. and Peñuelas, J.: Drought decreases soil enzyme activity in a Mediterranean holm oak forest, Soil Biol. Biochem., 37 , 455-461, 2005.

Schmitz, M. F., Atauri, J. A., de Pablo, C. L., Martín de Agar, P., Rescia, A. J., and Pineda, F. D.: Changes in land use in Northern Spain: effects of forestry management on soil conservation, Forest Ecol. Manag., 109, 137-150, 1998.

Sinsabaugh, R. L., Lauber, C. L., Weintraub, M. N., Ahmed, B., Allison, S. D., Crenshaw, C., Contosta, A. R., Cusack, D., Frey, S., Gallo, M. E., Gartner, T .B., Hobbie, S. E., Holland, K., Keeler, B. L., Powers, J. S., Stursova, M., Takacs-Vesbach, C., Waldrop, M. P., Wallenstein, M. D., Zak, D. R., and Zeglin, L. H.: Stoichiometry of soil enzyme activity at global scale, Ecol. Lett., 11, 1252-1264, 2008.

Smith, L. J. and Papendick, R. I.: Soil organic matter dynamics and crop residue management, in: Soil Microbial Ecology, edited by: Metting, B., Marcel Dekker, New York, 65-94, 1993.

Tabatabai, M. A.: Soil enzymes, in: Methods of analysis, part 2, 2nd Edn., edited by: Page, A. L., Miller, E. M., and Keeney, D. R., Agronomy, 9, 389-396, 1982.

Tabatabai, M. A. and Bremner, J. M.: Use of p-nitrophenyl phosphate for assay of soil phosphatase activity, Soil Biol. Biochem, 1, 301-307, 1969.

Trasar-Cepeda, C., Leirós, C., Gil-Sotres, F., and Seoane, S.: Towards a biochemical quality index for soils: an expression relating several biological and biochemical properties, Biol. Fert. Soils, 26, 100-106, 1998.

Úbeda, X. and Outeiro, L.: Physical and chemical effects offire on soil, in: Fire Effects on Soils and Restoration Strategies, edited by: Cerdà, A. and Robichaud, P. R., Science Publishers, CRC Press, Boca Raton, FL, 105-133, 2009.

Vance, E. D., Brookes, P. C., and Jenkinson, D. S.: An extraction method for measuring soil microbial biomass, Soil Biol. Biochem., 19, 703-707, 1987. 
Van der Putten, W. H., Bardgett, R. D., Bever, J. D., Bezemer, T. M., Casper, B. B., Fukami, T., Kardol, P., Klironomos, J. N., Kulmatiski, A., Schweitzer, J. A., Suding, K. N., Van de Voorde, T. F. J., and Wardle, D. A.: Plant-soil feedback: the past, the present and future challenges, J. Ecol., 101, 265-276, 2013.

Wic-Baena, C., Andrés-Abellán, M., Lucas-Borja, M. E., MartínezGarcía, E., García-Morote, F. A., Rubio, E., and López-Serrano, F. R.: Thinning and recovery effects on soil properties in two sites of a Mediterranean forest, in Cuenca Mountain (South-eastern of Spain), Forest Ecol. Manag., 308, 223-230, 2013.
Yeomans, J. and Bremner, J. M.: A rapid and precise method for routine determination of organic carbon in soil, Commun. Soil Sci. Plan., 19, 1467-1476, 1989. 